\title{
Theorizing the moderating roles of perceived service fairness and self-congruence on the relationship between experiential marketing, customer citizenship behavior and brand loyalty
}

\author{
Zichen Wang $^{1}$ \\ ${ }^{1}$ College of Innovation and Management Suan Sunandha Rajabhat University, Bangkok, Thailand
}

\begin{abstract}
In such a fierce market competition, brand loyalty and the extent to which consumers participate in the corporate value chain cycle are even more important. At present, scholars' research on customer behavior and brand loyalty are still relatively limited. Therefore, the purpose of this article is to use the subjective well-being and brand identity as the mediators, the perceived service fairness as the roles of moderating to explore the experiential marketing, probing into a relationship between the customer citizenship behavior and the brand loyalty to build a research framework as the basis for subsequent empirical research.
\end{abstract}

\section{Introduction}

With the intensification of competition among enterprises in recent years, quantities of enterprises have not only paid more and more attention to whether customers can participate in the process of value chain circulation of enterprise, but also constantly promote new ways in marketing methods to meet customer needs. The concept of experiential marketing and customer citizenship behavior came into being under such trends and circumstances. Nevertheless, with the emergence of service-dominant logic as a new marketing idea, the importance of customer citizenship behavior and experiential marketing becomes extremely apparent. Previous literature has proven that customer citizenship behavior is an important factor in behavioral intent $[1,2]$. An important factor in relationship quality [3], and the importance of brand equity Factors $[4,5]$. Whether consumers can participate in the process of enterprise value chain circulation can decide the enterprises how to win in the fierce market competition. This study hopes to be able to respond to the senses, feelings, thoughts, actions, and relationships of consumers in smart phone companies, and whether their customers are willing to volunteer to make business benefits for the behavior of the loyalty of the brand to do research, because the company regards the employees as free advertisements to customers, invisibly allows the customer to play a role in promotion, enabling the company to reduce costs and help the company to obtain a preferential competitive advantage [6]. At the same time, brand loyalty can not only reduce the marketing cost of the enterprise, but also create economic value and social benefits for the enterprise, due to the input cost for attracting a new customer is much higher than the spend of retaining an old customer, otherwise, the loss of the old customer could also cause the huge financial wastage for enterprises [7].

\section{Literature Review}

\subsection{S-O-R Theory}

Mehrabian and Russell (1974) developed the "Stimulus Organism Response" (S-O-R) model from the environmental psychology, which also explains the stimulation caused by different levels of the external environment (Stimuli, S). It affects people's internal state and physiology (Organism, O), which in turn affects people's behavioral responses (Response, R) [8].

The S-O-R model explains how the environment effect the individuals of markets and their interior behavioral states. The S-O-R model is a representative outcome of the relationship between physical environment and behavior. It considers the environment (product characteristics, brand reputation, price, promotion, display, music, Services, etc.) are stimuli that contain many clues that together affect the perception and cognitive state within the body, thus, forming the accepted or avoided behavioral feedback [9].

This study considers experiential marketing as stimuli (Stimuli, S), regards subjective well-being and brand identity mediating roles, as physiology (Organism, O), and considers outcome variables customer citizenship behavior and brand loyalty as a response (Response, R).

\subsection{Experiential Marketing}

Schmitt (1999) first proposed the concept and strategic experience module (SEM) of experiential marketing from the perspective of psychology [10]. He believes that experiential marketing is an individual customer who will feel a certain stimulus after inducing or participating in an 
event and will Motivate motivation to generate a thinking identity or purchase behavior. At the same time, Figure 1 shows the five dimensions of experiential marketing.

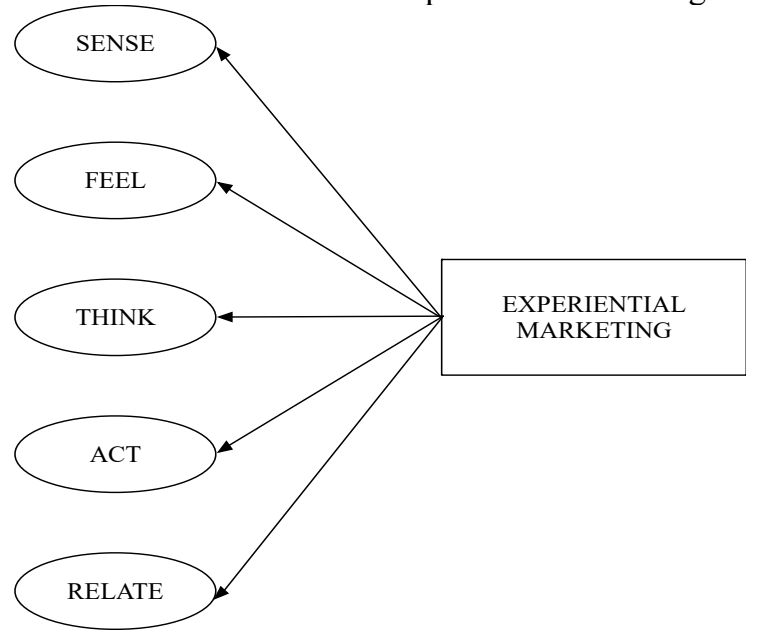

Fig1. Experiential marketing dimension Source: Schmitt, 1999

\subsection{Well-Being}

At present, the academic community widely agrees with the definition of subjective well-being by Diener (1985) [11], that is, subjective well-being refers to the definition of people's satisfaction in various fields of life according to their subjective rather than objective standards.

\subsection{Brand Identity}

Brand identity is the brand operator's desire for consumers to think about the brand and the brand's meaning and spirit. Brand identity refers to the determination of a brand by consumers, and consumers identify brands that reflect themselves and strengthen their identity $[12,13]$.

\subsection{Perceived Service Fairness}

Customers' judgment about the behavior of a service firm, which could either be positively or negatively, is what is known as perception of service fairness [14]. Customers' judgment of service fairness surface when their experience is compared to their fairness standards and they identify themselves as being either fairly or unfairly treated. Satisfied relationship tends to be the outcome of perceived service fairness [14]. The literature suggests that perceived service fairness is a multidimensional construct consisting of three dimensions $[15,16,17]$. These dimensions include: distributive, procedural and interactional fairness or justice. Previous studies have reported significant relationship between service fairness and customer loyalty.

\subsection{Brand Loyalty and Customer Citizenship Behavior}

Brand loyalty as a consumer's willingness to repeatedly purchase a branded product or service of its preference, and will not cause any external influence or any factor that may cause the consumer to have a transfer behavior [18]. The consumer's willingness to purchase is shaken and the brand continues to be selected. In the study of the premeasurement variables of brand loyalty, Veloutsou (2015) regards brand loyalty as a single facet and develops a brand loyalty scale with eight items [19]. Customer citizenship behavior represent a bundle of voluntary, extra role behavior that a customer exhibit which has positive impact on the overall performance of the organization [20].

\subsection{Influence of Experiential Marketing on its Outcome Variables}

The SOR theory based on environmental psychology [21], which explained that the stimuli caused by the external environmental level will affect people's internal state, physiology and thus affect people's behavioral responses. Hedhli, Chebat and Sirgy (2013) studied how shopping mall atmosphere affects shoppers' happiness, and then found that the mall's decoration and atmosphere are the most important factors affecting customer happiness [22]. Mousavi and Naam (2018) found that brand recognition has a positive effect on improving brand loyalty [23]. Based on the above statement, the following assumptions are made:

$\mathrm{H} 1$ : Experiential marketing has a positive influence on subjective well-being.

$\mathrm{H} 2$ : Experiential marketing has a positive influence on brand identity.

\subsection{Influence of Well-being on its Outcome Variables}

Social exchange theory suggests that a positive customer experience may motivate customers to reward by engaging in voluntary behavior [24]. In addition, individuals tend to participate in customer citizenship behavior when social exchange success occurs [25], for individuals who experience high-quality relationships may return and cooperate with each other (Bettencourt, 1997). That is, a different level of customer experience quality is expected to result in an increase or decrease in customer citizenship behavior [26]. A research on transformative retail services found that customer wellbeing will positively affect customer loyalty [27]. Based on the above statement, the following hypotheses are suggested:

$\mathrm{H} 3$ : Subjective well-being has a positive influence on customer citizenship behavior.

H4: Subjective well-being has a positive influence on brand loyalty.

\subsection{Influence of Brand Identity on its Outcome Variables}

$\mathrm{He}, \mathrm{Li}$ and Harris (2012) confirms the pivotal role of brand identification in brand loyalty development and stresses the mediation effect of brand identification on the effects of brand identity on the path to brand loyalty [28]. The process of brand identity and communication in effective is important for an enterprise to drive customer citizenship 
behavior [29]. Based on the above statement, the following hypotheses are suggested:

H5: Brand identity has a positive influence on customer citizenship behavior.

H6: Brand identity has a positive influence on brand loyalty.

\subsection{Moderating Roles of Self-congruence}

Yu, Assor and Liu (2015) found in a psychology-based study that self-consistency has a positive effect on subjective well-being [30]. Behavior theory believes that when consumers participate in social activities that match their personal interests and abilities, they will produce happiness in meaningful activities [31]. Association theory holds that individuals are satisfied with positive cognitive events [32]. Demand satisfaction theory believes that consumers can create social well-being by actively participating in healthy and meaningful social activities [33]. If the brand image of the product is more consistent with the image of the consumer itself, then the consumer's sense of identity with the brand is easier [34]. Based on the above statement, the following assumptions are made:

H7: The higher the self-congruence, the more positive the impact of experiential marketing on subjective wellbeing.

H8: The higher the self-congruence, the more positive the impact of experiential marketing on brand identity.

\subsection{Moderating Roles of Perceived Service Fairness}

A study on the effects of perceived service fairness on emotions, and behavioral intentions in restaurants, confirmed that perceived service fairness where significantly related to brand loyalty [35]. A similar study by Kwortnik Jr and Han (2011) also uncovered that two out of the three dimensions of service fairness; distributive and interactional fairness had more effect on customer loyalty than the procedural dimension [36]. The findings confirmed that service fairness has the overall effect on customer loyalty. Because according to the social exchange theory, the customer's pleasure will be produced after the consumption, the psychological identity or the relationship to specific businesses will be maintained. Willingness will drive customers through word-to-mouth recommendation, receive publicity feedback and other beneficial behaviors for the companies [37]. Drawing on the social exchange theory and frustration-aggression theory, this paper argues that perceived service fairness influence customer citizenship behavior [38]. Based on the above statement, the following hypotheses are suggested:

H9: The higher the perceived service fairness, the more positive the impact of subject well-being on customer citizenship behavior.

H10: The higher the perceived service fairness, the more positive the impact of brand identity on customer citizenship behavior.

H11: The higher the perceived service fairness, the more positive the impact of subject well-being on brand loyalty.

H12: The higher the perceived service fairness, the more positive the impact of brand identity on brand loyalty

\section{Methodology}

After clarifying the research motivation, background and research purpose in Chapter 1, and related literature discussion and hypothesis inference in Chapter 2, after determining the research direction, we then establish the research framework of this research.

After the literature collection and collation, the research framework of this study is composed of seven variables, which are experience marketing, subjective well-being, brand identity, customer civic behavior, brand loyalty, self-consistency, and perceived service fairness. The theory content shows that the stimulation caused by different levels of the external environment (Stimuli, S) will affect people's internal state, physiology (Organism, $\mathrm{O})$, which in turn affects people's behavioral responses (Response, R), as shown in Figure 2.

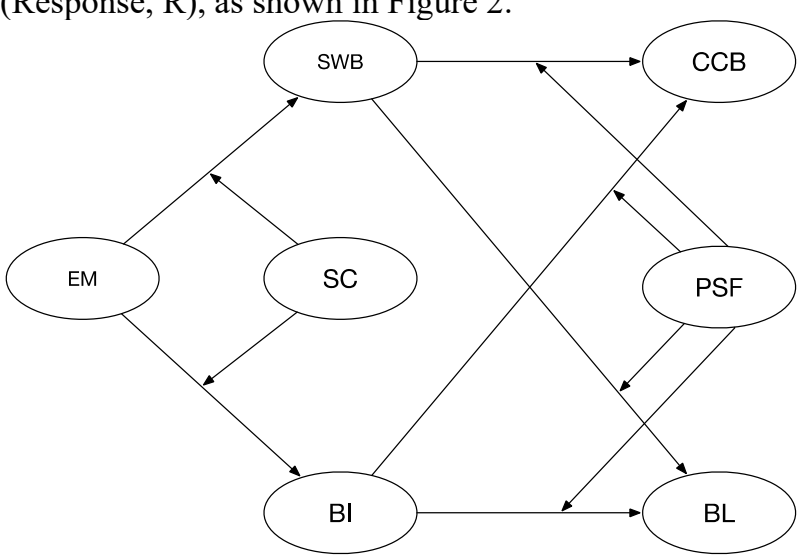

Fig2. Conceptual Model of the Study

\section{Conclusion}

The main purpose of this article is to propose a conceptual model that describes the relationship between customer experience and brand loyalty during the shopping process and voluntary customer behavior that is beneficial to the company.

At the same time, the possible mediating role of consumer happiness and brand identity in the relationship between experiential marketing and dependent variables is proposed. At the same time, the moderation effect of the degree of consistency between consumers and brands and the degree of fairness in the consumption process are proposed. In order to bridge the gaps in the literature, this article recommends the introduction of moderator and mediator. Therefore, the basic contribution of this article is that the proposed conceptual model provides a basis for good research.

\section{References}

1. Ali, F., Ryu, K., \& Hussain, K. (2016). Influence of experiences on memories, satisfaction and behavioral intentions: A study of creative tourism. Journal of 
Travel \& Tourism Marketing, 33(1), 85-100.

2. Dolbec, P. Y. \& Chebat, J. C. (2013). The impact of a flagship vs. a brand store on brand attitude, brand attachment and brand equity. Journal of Retailing, 89(4), 460-466.

3. Jung, L. H. \& Soo, K. M. (2012). The effect of brand experience on brand relationship quality. Academy of Marketing Studies Journal, 16(1), 87-98.

4. Dolbec, P. Y., \& Chebat, J. C. (2013). The impact of a flagship vs. a brand store on brand attitude, brand attachment and brand equity. Journal of Retailing, 89(4), 460-466.

5. Kumar, R. S., Dash, S., \& Purwar, P. C. (2013). The nature and antecedents of brand equity and its dimensions. Marketing Intelligence \& Planning, 31(2), 141-159.

6. Fowler, J. G. (2013). Customer citizenship behavior: an expanded theoretical understanding. International Journal of Business and Social Science, 4(5), 1-8.

7. Rosenbaum, M. S., \& Massiah, C. A. (2007). When customers receive support from other customers: exploring the influence of intercustomer social support on customer voluntary performance. Journal of Service Research, 9(3), 257-270.

8. Mehrabian, A. \& Russell, J. A. (1974). An Approach to Environmental Psychology, Massachusetts: The MIT Press.

9. Donovan, R. J., Rossiter, J. R., Marcoolyn, G., \& Nesdale, A. (1994). Store atmosphere and purchasing behavior. Journal of Retailing, 70(3), 283-294.

10. Schmitt, B. (1999). Experiential marketing. Journal of Marketing Management, 15(13), 53-67.

11. Diener, E., Emmons, R. A., Larsen, R. J., \& Griffin, S. (1985). The satisfaction with life scale. Journal of Personality Assessment, 49(1), 71-75.

12. Azoulay, A., \& Kapferer, J. N. (2003). Do brand personality scales really measure brand personality?. Journal of Brand Management, 11(2), 143-155.

13. Bhattacharya, C. B., \& Sen, S. (2003). Consumercompany identification: A framework for understanding consumers' relationships with companies. Journal of Marketing, 67(2), 76-88.

14. Giovanis, A., Athanasopoulou, P., \& Tsoukatos, E. (2013). Service fairness, service quality and relationship quality evaluation effects on customer loyalty. Paper presented at the 6th Annual Conference of the EuroMed Academy of Business, 1028-1046.

15. Clark, M. N., Adjei, M. T., \& Yancey, D. N. (2009). The impact of service fairness perceptions on relationship quality. Services Marketing Quarterly, 30(3), 287-302.

16. Friman, M., Gärling, T., Millett, B., Mattsson, J., \& Johnston, R. (2002). An analysis of international business-to-business relationships based on the Commitment-Trust theory. Industrial Marketing Management, 31(5), 403-409.
17. Meng, J. G., \& Elliott, K. M. (2008). Predictors of relationship quality for luxury restaurants. Journal of Retailing and Consumer Services, 15(6), 509-515.

18. Kim, D., Magnini, V. P., \& Singal, M. (2011). The effects of customers' perceptions of brand personality in casual theme restaurants. International Journal of Hospitality Management, 30(2), 448-458.

19. Veloutsou, C. (2015). Brand evaluation, satisfaction and trust as predictors of brand loyalty: the mediatormoderator effect of brand relationships. Journal of Consumer Marketing, 32(6), 405-421.

20. Lin, Y. L., Liu, H. W., \& Ngo, P. T. (2016). Silence is not golden: the effects of prohibitive voice on customer citizenship behaviors. International Business Research, 9(9), 24-33.

21. Mehrabian, A., \& Russell, J. A. (1974). An approach to environmental psychology. the MIT Press.

22. El Hedhli, K., Chebat, J. C., \& Sirgy, M. J. (2013). Shopping well-being at the mall: Construct, antecedents, and consequences. Journal of business research, 66(7), 856-863.

23. Mousavi, S. M. \& Naami, A. (2018). The mediating role of the brand preference in bank advertising and brand loyalty. Revista Publicando, 5(15), 858-875.

24. Lishan, X. I. E., Patrick, P. O. O. N., \& ZHANG, W. (2017). Brand experience and customer citizenship behavior: the role of brand relationship quality. Journal of Consumer Marketing, 34(3), 268280.

25. Lawler, E. J. (2001). An affect theory of social exchange. American Journal of Sociology, 107(2), 321-352.

26. Kim, H. S. \& Choi, B. (2016). The effects of three customer-to-customer interaction quality types on customer experience quality and citizenship behavior in mass service settings. Journal of Services Marketing, 30(4), 384-397.

27. Troebs, C. C., Wagner, T., \& Heidemann, F. (2018). Transformative retail services: Elevating loyalty through customer well-being. Journal of Retailing and Consumer Services, 45, 198-206.

28. He, H., Li, Y., \& Harris, L. (2012). Social identity perspective on brand loyalty. Journal of Business Research, 65(5), 648-657.

29. Porricelli, M. S., Yurova, Y., Abratt, R., \& Bendixen, M. (2014). Antecedents of brand citizenship behavior in retailing. Journal of retailing and consumer services, 21(5), 745-752.

30. Yu, S., Assor, A., \& Liu, X. (2015). Perception of parents as demonstrating the inherent merit of their values: Relations with self - congruence and subjective well - being. International Journal of Psychology, 50(1), 70-74.

31. Argyle, M., \& Crossland, J. (1987). The dimensions of positive emotions. British Journal of Social Psychology, 26(2), 127-137.

32. Stones, M. J., \& Kozma, A. (1985). Structural 
relationships among happiness scales: A second order factorial study. Social Indicators Research, 17(1), 1928.

33. Ryan, R. M., \& Deci, E. L. (2000). Intrinsic and extrinsic motivations: Classic definitions and new directions. Contemporary Educational Psychology, 25(1), 54-67.

34. Malär, L., Krohmer, H., Hoyer, W. D., \& Nyffenegger, B. (2011). Emotional brand attachment and brand personality: The relative importance of the actual and the ideal self. Journal of marketing, 75(4), 35-52.

35. Namkung, Y., \& Jang, S. C. (2010). Effects of perceived service fairness on emotions, and behavioral intentions in restaurants. European journal of marketing, 44(9), 1233-1259.

36. Kwortnik Jr, R. J., \& Han, X. (2011). The influence of guest perceptions of service fairness on lodging loyalty in China. Cornell Hospitality Quarterly, 52(3), 321-332.

37. Sun, N., \& Guo, G. (2016). Customer Commitment, Self-Enhancement and Customer Citizenship Behavior: Driving Mechanism and Moderating Effect from the Perspective of Social Exchange Theory. Management Review, 28(12), 187-197.

38. Yi, Y., \& Gong, T. (2008). The effects of customer justice perception and affect on customer citizenship behavior and customer dysfunctional behavior. Industrial Marketing Management, 37(7), 767-783. 